\title{
PEMBERIAN EKSTRAK JERUK LEMON (Citrus limon) PADA IKAN KAKAP PUTIH (Lates calcarifer) DALAM PENCEGAHAN INFEKSI VNN
}

\author{
Ketut Mahardika $^{a^{*}}$, Indah Mastuti ${ }^{a}$, Monica Eka Satriyani ${ }^{\text {, }}$ Zafran $^{\text {a }}$ \\ ${ }^{a}$ Balai Besar Riset Budidaya Laut dan Penyuluhan Perikanan, Gondol, Buleleng-Bali \\ ${ }^{\mathrm{b}}$ Mahasiswa Politeknik Kelautan dan Perikanan, Sidoarjo, Surabaya \\ *Koresponden penulis : kmahardika@yahoo.com
}

\begin{abstract}
Abstrak
Jeruk lemon (Citrus limon) merupakan buah yang kaya akan vitamin C dan serat. Penelitian ini bertujuan untuk mengetahui pengaruh pemberian ekstrak buah jeruk lemon pada juvenil kakap putih (Lates calcarifer) untuk mencegah infeksi VNN (viral nervous necrosis). Masing-masing 50 ekor kakap putih sehat ukuran panjang $10,44 \pm 1,44 \mathrm{~cm}$ dan berat 16,86 $\pm 4,91 \mathrm{~g}$ ditempatkan dalam 4 bak fiber volume 500 Liter. Setiap ikan diberi pakan pelet komersial yang mengandung: $100 \mathrm{~mL}$ air seduhan dari $100 \mathrm{~g}$ daging dan kulit jeruk lemon/kg pakan, $100 \mathrm{~g}$ ekstrak daging jeruk lemon/kg pakan, $100 \mathrm{~g}$ ekstrak daging dan kulit jeruk lemon/1 kg pakan, dan $100 \mathrm{~mL}$ air tawar steril/kg pakan sebagai kontrol. Pakan diberikan dua kali sehari secara ad libitum selama 6 minggu. Hasil penelitian menunjukkan bahwa pertumbuhan ikan tidak berbeda nyata $(p>0,05)$ dari keempat perlakuan tersebut. Jumlah leukosit dan kadar glukosa darah dari ikan yang diberi pakan dengan air seduhan jeruk lemon lebih tinggi (18,967 $\mathrm{sel} / \mathrm{mm}^{3}$ dan $\left.97,0 \mathrm{mg} / \mathrm{dL}\right)$ dibandingkan dengan perlakuan lainnya. Akan tetapi, persentase hematokrit dan hemoglobin dari ikan yang diberi pakan dengan daging lemon maupun daging dan kulit lemon lebih tinggi (37,67$39,33 \%$ dan 8,18-8,27 g/dL) dibandingkan dua perlakuan lainnya (24,33-25,33\% dan 7,0-7,23 g/dL). Uji tantang dengan inokulum VNN menunjukkan ikan yang diberi pakan dengan air seduhan jeruk lemon lebih baik dalam menekan mortalitas ikan (sintasan 30\%) dibandingkan perlakuan lainnya (sintasan 15-20\%).
\end{abstract}

Kata kunci : Jeruk lemon, kakap putih, VNN.

\begin{abstract}
Lemon (Citrus limon) is rich in vitamin $\mathrm{C}$ and fiber. This study aims to determine the effect of lemon extract on sea bass (Lates calcarifer) to prevent VNN (viral nervous necrosis) infection. Each of the 50 healthy sea bass (total length of $10.44 \pm 1.44 \mathrm{~cm}$ and weight of $16.86 \pm 4.91 \mathrm{~g}$ ) placed in 500 Liter volume of fiber tank. Fish was given commercial pellet feed containing: $100 \mathrm{~mL}$ of brewing water from $100 \mathrm{~g}$ of flesh and lemon peel/kg of feed, $100 \mathrm{~g}$ of flesh lemon extract/ $\mathrm{kg}$ of feed, $100 \mathrm{~g}$ of flesh and lemon peel extract/1 kg of feed, and $100 \mathrm{~mL}$ of sterile fresh water $/ \mathrm{kg}$ of feed as control. Feed was given twice a day on ad libitum for 6 weeks. The results showed that fish growth was not significantly different $(\mathrm{p}>0.05)$ from the four treatments. Leukocyte and blood glucose levels from fish fed with lemon brew water were higher $\left(18,967\right.$ cells $/ \mathrm{mm}^{3}$ and $\left.97.0 \mathrm{mg} / \mathrm{dL}\right)$ compared to other treatments. However, the percentage of hematocrit and hemoglobin from fish fed with both lemon flesh extract and combination of lemon flesh and peel extract were higher (37.67-39.33\% and 8.18-8.27 g/dL) compared to the other two treatments $(24,33-25.33 \%$ and $7.0-7.23 \mathrm{~g} / \mathrm{dL})$. The challenge test with the VNN inoculum showed that fish fed with lemon brewing water was better to reduce fish mortality (30\% survival rate) than other treatments (15-20\% survival rate).
\end{abstract}

Keywords : Lemon, sea bass, VNN.

\section{PENDAHULUAN}

Viral Nervous Necrosis (VNN) merupakan penyakit yang disebabkan oleh piscine nodavirus. Infeksi VNN dapat menimbulkan kematian massal pada budidaya ikan kerapu (Epinephelus sp.) dan kakap putih (Lates calcarifer) di hatchery maupun keramba jaring apung. Infeksi VNN dilaporkan hampir terjadi sepanjang tahun pada sentra budidaya ikan kerapu dan kakap putih di Bali Utara $[1,2]$. Prevalensi infeksi virus VNN lebih banyak terjadi pada bulan Maret sampai bulan Juli, dan meningkat pada bulan November. Kejadian infeksi VNN dan peningkatan konsentrasi populasi bakteri pada hati ikan budidaya dipengaruhi oleh suhu perairan dan kadar ammonia [2]. Upaya pencegahan terhadap infeksi virus ini telah dilakukan oleh pembudidaya ikan seperti penggunaan sand filter pada intake water dan penggunaan bahan kimia untuk mengurangi infeksi parasit dan bakteri yang dapat memicu 
infeksi virus. Akan tetapi penggunaan secara berlebihan dari bahan kimia dan antibiotik dapat meningkatkan resistensi mikroorganisme. Residu bahan kimia dan antibiotik dapat menumpuk di tanah atau sedimen dan menjadi berbahaya bagi lingkungan [3]. Penggunaaan tanaman herbal atau medis dapat menjadi alternatif pencegahan maupun pengobatan ikan budidaya terhadap infeksi mikroorganisme patogen.

Tumbuhan medis adalah produk praperawatan, pengobatan dan imunostimulasi yang sangat populer dalam kesehatan manusia dan hewan. Salah satu tanaman medis tersebut adalah jeruk lemon. Jeruk lemon mengandung zat gizi esensial meliputi karbohidrat, potasium, folat, kalsium, thiamin, niacin, vitamin B6, fosfor, magnesium, tembaga, riboflavin, asam pantotenat dan senyawa fitokimia lainnya. Karbohidrat dalam jeruk lemon merupakan karbohidrat sederhana, yaitu fruktosa, glukosa dan sukrosa. Karbohidrat kompleksnya berupa polisakarida non - pati 11 (serat makanan). Lemon juga mengandung bioflavonoid, asam dan minyak minyak volatil pada kulitnya seperti limonen $( \pm$ $70 \%$ ), $\alpha$-terpinen, $\alpha$-pinen, $\beta$-pinen, citrat, dan kumarin [4]. Buah lemon mengandung asam sitrat $3,7 \%$, minyak atsiri $2,5 \%$ dan asam askorbat $40-50 \mathrm{mg}$ per $100 \mathrm{~g}$. Ekstrak jus dari buah lemon lokal maupun lemon impor diketahui memiliki aktivitas antioksidan [5]. Senyawa fenolik lemon bersifat sitoprotektif dengan membersihkan anion superoksida, radikal hidroksil, dan hidrogen peroksida, sehingga mengurangi peroksidasi lemak [6]. Jus lemon dapat digunakan untuk mengurangi efek negatif MSG (monosodium glutamate) pada sel purkinye dari tikus putih jantan [7]. Minyak esensial dari kulit jeruk lemon dan buah pohon argan (Argania spinosa) juga efektif digunakan untuk menghambat aktivitas bakteri patogen ikan [3]. Tujuan dari penelitian ini adalah untuk mengetahui pengaruh pemberian ekstrak buah jeruk lemon pada juvenil kakap putih untuk mencegah infeksi VNN.

\section{BAHAN DAN METODE}

\section{Ikan uji}

Ikan yang digunakan dalam penelitian ini adalah juvenil kakap putih sehat (jumlah 200 ekor dengan rata-rata panjang total: $10,44 \pm 1,44$ $\mathrm{cm}$ dan berat $16,86 \pm 4,91 \mathrm{~g}$ ) yang berasal dari pembenihan di hatchery Balai Besar Riset Perikanan Budidaya Laut dan Penyuluhan
Perikanan (BBRBLPP), Gondol, Bali. Ikan-ikan tersebut direndam dalam $100 \mathrm{ppm}$ formalin selama 60 menit dengan aerasi kuat untuk menghilangkan parasit yang menempel ditubuhnya. Selanjutnya ikan-ikan tersebut diaklitimasi selama 1 minggu dalam 2 bak beton volume $500 \mathrm{~L}$. Masing-masing 50 ekor ikan ditempatkan dalam bak fiber volume $500 \mathrm{~L}$ (total 4 bak) dengan sistem air mengalir.

\section{Air seduhan dan ekstrak jeruk lemon}

Jeruk lemon diperoleh dari hasil perkebunan jeruk lemon skala rumah tangga di sekitar BBRBLPP. Jeruk tersebut dipilih yang sudah matang dengan warna kuning dan bau yang khas. Jeruk tersebut dicuci dengan air tawar agar bersih. Sebanyak $100 \mathrm{~g}$ dari daging maupun keseluruhan (daging dan kulit) jeruk lemon ditimbang dan diiris tipis. Masing-masing $100 \mathrm{~g}$ daging jeruk lemon, dan daging serta kulit jeruk lemon ditambahkan dengan $100 \mathrm{~mL}$ air tawar steril dan di blender sampai halus. Ekstrak jeruk tersebut diperas dan disaring dengan saringan rotifer (mesh size $200 \mu \mathrm{m}$ ). Sedangkan air seduhan lemon dibuat dengan menyeduh $100 \mathrm{~g}$ irisan daging dan kulit jeruk lemon dengan $100 \mathrm{~mL}$ air mendidih $\left(100{ }^{\circ} \mathrm{C}\right)$ dan dibiarkan selama 15 menit. Air seduhan tersebut disaring dengan saringan rotifer.

\section{Pencampuran air seduhan dan ekstrak jeruk lemon dalam pakan pelet komersial}

Masing-masing $100 \mathrm{~mL}$ dari air seduhan dan ekstrak jeruk lemon dicampurkan ke dalam $1 \mathrm{~kg}$ pakan pelet komersial dengan menyemprotkan air seduhan dan ekstrak jeruk lemon pada pakan yang ditempatkan dalam nampan secara merata. Pakan tersebut selanjutnya diangin keringkan pada suhu ruang $\left(27-28{ }^{\circ} \mathrm{C}\right)$ selama 1 malam. Setelah kering, pakan tersebut disimpan dalam botol kaca pada suhu $4{ }^{\circ} \mathrm{C}$ (kulkas).

\section{Pemberian air seduhan dan ekstrak jeruk lemon pada ikan uji}

Setiap ikan per bak diberi pakan pelet komersial yang mengandung: $100 \mathrm{~g}$ ekstrak daging jeruk lemon/kg pakan, $100 \mathrm{~g}$ ekstrak daging dan kulit jeruk lemon/ kg pakan, dan 100 $\mathrm{mL}$ air tawar steril/kg pakan sebagai kontrol. Pakan diberikan dua kali sehari secara ad libitum selama 6 minggu. Kotoran ikan dibersihkan setiap hari untuk menjaga kebersihan bak. 


\section{Parameter uji}

\section{Pertumbuhan ikan}

Pertumbuhan ikan pada masing-masing perlakuan dihitung dengan mengukur Panjang dan berat semua ikan/perlakuan setiap 2 minggu sekali. Ikan-ikan tersebut dianastesi dengan minyak cengkeh (eugenol: $0,1 \mathrm{~mL} / \mathrm{L}$ air laut) sebelum dilakukan pengukuran panjang total dan penimbangan berat tubuh ikan. Hasil perhitungan dianalisa anova dan uji Duncan.

\section{Sel darah}

Pengamatan sel darah dilakukan setelah 6 minggu pasca pemeliharaan. Pengamatan darah digunakan untuk mengetahui pengaruh ekstrak jeruk lemon terhadap rataan jumlah hematologi pada ikan kakap putih. Pengambilan sel darah dilakukan dengan cara sampling acak 3 ekor/bak/perlakuan agar didapat rataan pada masing-masing parameter sel darah. Pengambilan darah dilakukan pada bagian bawah linea lateralis di bagian sirip ekor (caudal fin) yaitu melalui vena caudalis. Sel darah yang diamati yaitu eritrosit dan leukosit yang diukur dengan alat haemocytometer (darah dari 3 ekor ikan digabung dalam satu microtube), hematokrit dengan micro-capillary [8], haemoglobin serta glukosa dengan kit Easy Touch GCHb (darah dari masing-masing ikan).

\section{Uji tantang dengan inokulum virus VNN}

Inokulum virus VNN dibuat mengikuti prosedur yang sebelumnya telah dilaporkan oleh [9] dengan lethal dosis sebesar $80 \%$. Sebanyak 20 ekor ikan uji dari masing-masing perlakuan ditempatkan dalam bak plastik volume $150 \mathrm{~L}$. Ikan-ikan tersebut dianastesi dengan minyak cengkeh. Uji tantang dilakukan dengan menyuntikkan inokulum virus VNN sebanyak 0,1 mL/ekor. Ikan-ikan tersebut dipelihara dan diamati gejala klinis dan mortalitas yang terjadi selama 14 hari. Hasil uji dianalisa secara dekriptif.

\section{HASIL DAN PEMBAHASAN}

Pengamatan laju pertumbuhan pada ikan kakap putih yang diberi pakan dengan penambahan air seduhan dan ekstrak jeruk lemon mengalami peningkatan yang lebih baik dibandingkan dengan kontrol walaupun nilainya tidak berbeda nyata $(\mathrm{P}>0,05)$. Selain menjadi imunostimulan, penambahan ekstrak jeruk lemon kemungkinan juga dapat menjadi atraktan untuk merangsang pertumbuhan ikan kakap putih. Pertambahan rata-rata panjang total dan berat ikan kakap putih selama 6 minggu pemeliharaan seperti terlihat dalam gambar $1 \mathrm{a}$ dan $\mathrm{b}$.
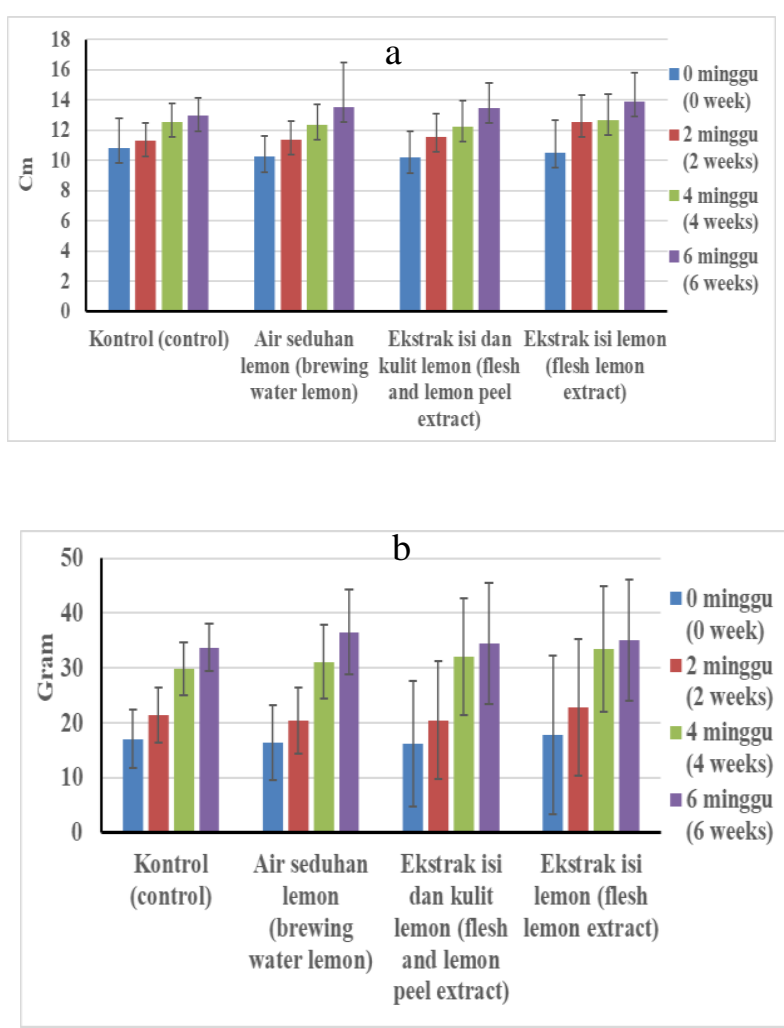

Gambar 1. Pertambahan panjang; (a), dan pertambahan berat; (b) dari ikan kakap putih yang diberi pakan dengan penambahan ekstrak jeruk lemon selama 6 minggu.

Sintasan ikan selama 6 minggu pemeliharaan pada semua perlakuan mencapai $100 \%$. Semua ikan di setiap perlakuan terlihat sehat dengan nafsu makan yang tinggi dan berenang normal.

Kadar eritrosit dalam tubuh ikan dapat dijadikan sebagai indikator kondisi kesehatan ikan. Kadar eritrosit yang tinggi menujukkan ikan dalam kondisi stress, sedangkan kadar eritrosit yang cenderung rendah menandakan ikan mengalami anemia [10]. 


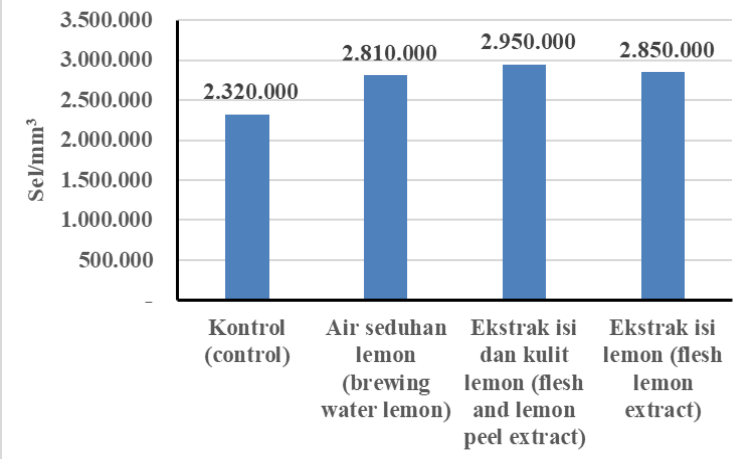

Gambar 2. Rataan kadar eritrosit $\left(\mathrm{sel} / \mathrm{mm}^{3}\right)$ pada ikan kakap putih setelah pemberian ekstrak jeruk lemon selama 6 minggu

Gambar 2 menunjukkan bahwa total eritrosit ikan kakap putih setelah 6 minggu pemberian ekstrak jeruk lemon sedikit lebih tinggi dibandingkan dengan kontrol. Namun nilai tersebut masih dalam kisaran normal. Menurut Roberts [11], total eritrosit normal pada ikan teleost adalah $1,05 \times 10^{6}-3,0 \times 10^{6} \mathrm{sel} / \mathrm{mm}^{3}$. Jumlah rataan eritrosit normal juga ditunjukkan pada ikan gurame (Osphronemus gouramy Lac.) yang diberi pakan dengan penambahan ekstrak bunga rosella (Hibiscus sabdariffa L.). Jumlah rataan eritrosit yang normal menandakan ikan dalam keadaan sehat, dimana fungsi darah dalam mengangkut oksigen $\left(\mathrm{O}_{2}\right)$ dari luar tubuh dan mensuplainya ke organ-organ yang memerlukan serta proses pembuangan karbondioksida $\left(\mathrm{CO}_{2}\right)$ ke luar tubuh ikan berjalan normal atau tidak terganggu [10]. Namun hal berbeda dilaporkan pada ikan mas (Cyprinus carpio) yang diberi pakan dengan penambahan ekstrak daun sirsak (Annona muricata), dimana total eritrosit setelah 14 hari cenderung menurun berkisar antara $0,55 \times 10^{6}-1,17 \times 10^{6} \mathrm{sel} / \mathrm{mm}^{3}$. Hal tersebut diduga disebabkan karena ikan uji mengalami anemia sehingga terjadi penurunan nafsu makan [12].

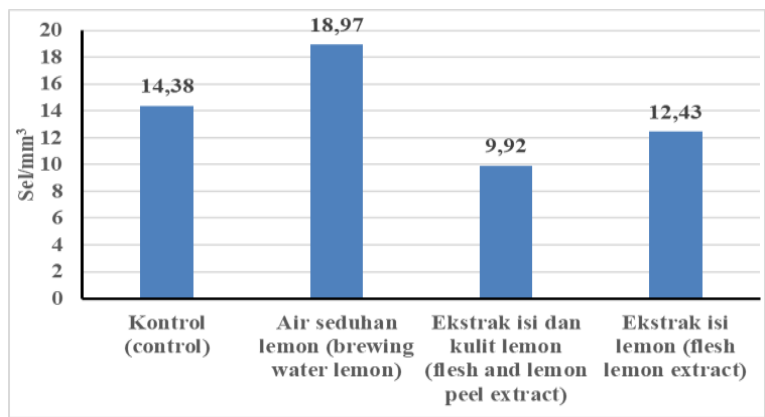

Gambar 3. Rataan kadar leukosit $\left(\mathrm{sel} / \mathrm{mm}^{3}\right)$ pada ikan kakap putih setelah pemberian ekstrak jeruk lemon selama 6 minggu
Rataan jumlah leukosit ikan kakap putih yang diberi perlakuan ekstrak jeruk lemon berkisar antara 9.92-18.97 sel/ $/ \mathrm{mm}^{3}$ (Gambar 3). Jumlah leukosit tertinggi terdapat pada ikan kakap putih dengan perlakuan air seduhan lemon, sedangkan rataan jumlah leukosit terendah terdapat pada perlakuan ekstrak daging dan kulit lemon. Jumlah leukosit tersebut masih dalam batas normal. Jumlah leukosit ikan kerapu macan (Epinephelus fuscoguttatus) setelah transportasi dan 7 hari pemeliharaan berkisar antara $2,9 \times 10^{4}$ $4,27 \times 10^{4} \mathrm{sel} / \mathrm{mm}^{3}$ [13]. Perbedaan jumlah leukosit tergantung dari keadaan ikan ketika pemeliharaan. Ikan yang stress selama proses pemeliharaan akan mengakibatkan meningkatnya jumlah leukosit. Jumlah leukosit akan meningkat jika terjadi perubahan lingkungan pemeliharaan atau adanya infeksi yang disebabkan oleh virus, bakteri, parasit maupun jamur [14].

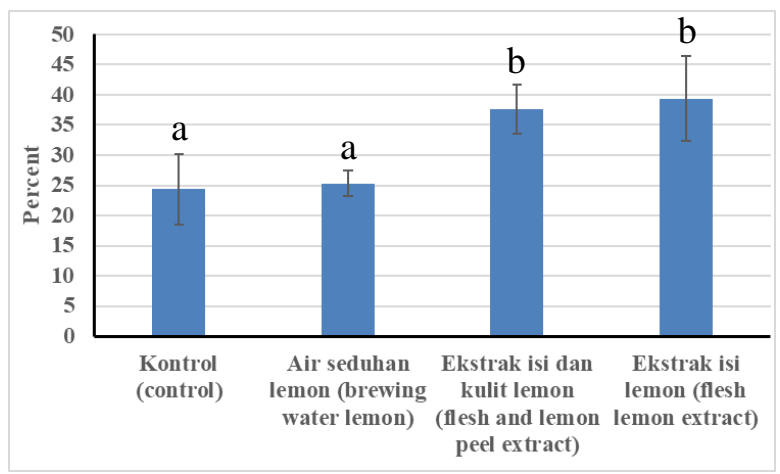

Gambar 4. Nilai hematokrit (\%) pada ikan kakap putih setelah pemberian ekstrak jeruk lemon selama 6 minggu

Nilai hematokrit dari ikan kakap putih yang diberi pakan dengan penambahan ekstrak daging maupun ekstrak daging dan kulit jeruk lemon lebih tinggi $(\mathrm{p}<0,05) \quad(37,67 \pm 4,04 \quad$ dan $39,33 \pm 7,02 \%$ ) dibandingkan dengan ikan kakap putih yang diberi pakan dengan penambahan air seduhan jeruk lemon maupun kontrol $(25,33 \pm 2,08$ dan $24,33 \pm 5,77 \%$, Gambar 4). Nilai hematokrit ini masih dalam kisaran standar normal. Nilai hematokrit ikan kakap putih sebesar 28,75 \%, sedikit lebih rendah dibandingkan dengan ikan bandeng (Chanos chanos) dan beberapa jenis ikan kerapu [8]. Nilai hematokrit menurun jika ikan ikan terkena infeksi penyakit atau nafsu makan menurun [15]. Apabila ikan memiliki nilai hematokrit < 20\% maka ikan tersebut mengalami anemia, sedangkan jika nilai hematokrit ikan tinggi cenderung mengalami stress [16]. 


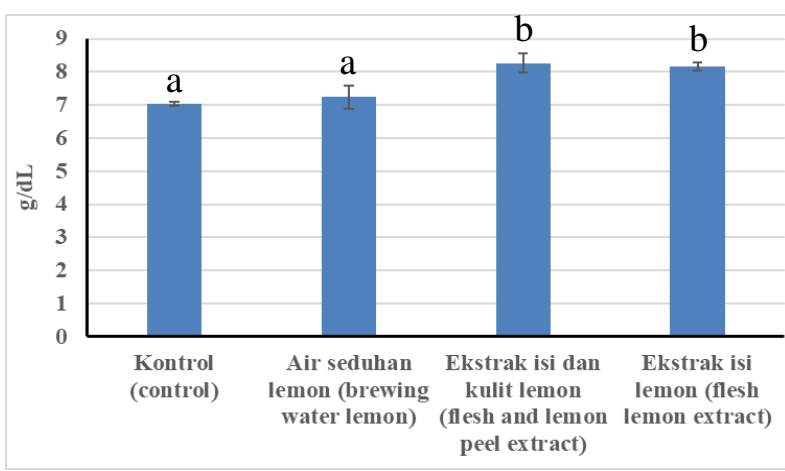

Gambar 5. Rataan kadar hemoglobin (g/dL) pada ikan kakap putih setelah pemberian ekstrak jeruk lemon selama 6 minggu

Seperti halnya nilai eritrosit dan hematokrit, kadar hemoglobin ikan kakap putih yang diberi pakan dengan penambahan ekstrak daging lemon maupun ekstrak daging dan kulit lemon menunjukkan nilai yang lebih tinggi $(\mathrm{p}<0,05)$ $(8,17 \pm 0,12$ dan $8,27 \pm 0,29 \mathrm{~g} / \mathrm{dL})$ dibandingkan dengan ikan kakap putih yang diberi pakan dengan penambahan air seduhan lemon maupun kontrol $(7,23 \pm 0,35$ dan 7,03 $\pm 0,06 \mathrm{~g} / \mathrm{dL}$, Gambar 5). Hal ini disebabkan oleh terganggunya fungsi hemoglobin dalam mengedarkan oksigen ke seluruh tubuh [17]. Peningkatan kadar hemoglobin pada ikan dapat disebabkan oleh aktivitas flavonoid yang terkandung dalam buah atau tanaman. Aktivitas flavonoid dapat meningkatkan kerja organ-organ penghasil darah sehingga produksi darah meningkat [18].

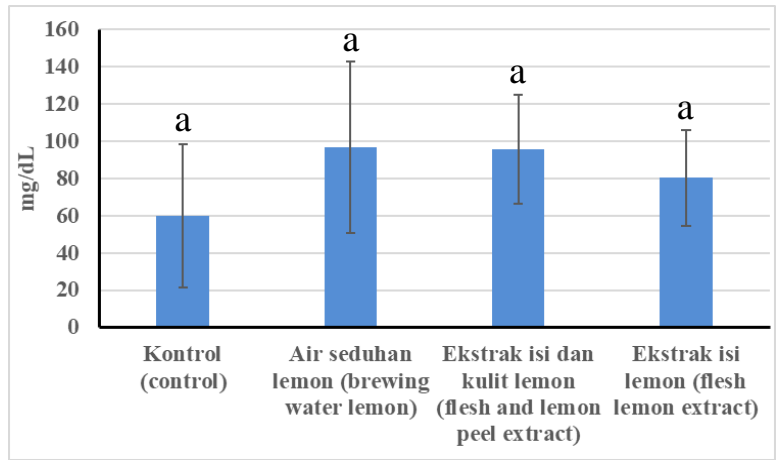

Gambar 6. Rataan kadar glukosa (mg/dL) pada ikan kakap putih setelah pemberian ekstrak jeruk lemon selama 6 minggu

Kadar glukosa darah ikan kakap putih dari ketiga perlakuan pemberian pakan dengan penambahan air seduhan maupun ekstrak jeruk lemon lebih tinggi $(97,0 \pm 46,03,95,67 \pm 29,09$ dan $80,33 \pm 25,79 \mathrm{mg} / \mathrm{dL})$ dibandingkan dengan kontrol $(60,0 \pm 38,35$, Gambar 6). Akan tetapi nilai tersebut tidak berbeda nyata $(\mathrm{p}>0,05)$ antar perlakuan. Kadar glukosa ikan dilaporkan berkisar antara 60-90 mg/dL [19]. Hal ini menunjukkan bahwa kadar glukosa melebihi rentangan nilai dari kadar glukosa normal. Keadaan tersebut diduga disebabkan karena pemberian pakan dengan metode ad libitum yang menyebabkan ikan kakap putih dalam kondisi kekenyangan, sehingga energi yang didapat terlalu banyak dan menyebabkan kadar glukosa meningkat. Kandungan vitamin dalam lemon kemungkin mempengaruhi nafsu makan ikan sehingga ikan akan makan lebih banyak. Hal tersebut juga didukung dengan pertambahan berat badan ikan kakap yang diberi air seduhan maupun ekstrak lemon lebih tinggi dibandingkan dengan ikan kontrol. Naiknya glukosa darah menandakan bahwa ikan dalam keadaan kenyang, dengan arti lain nafsu makan berkurang karena energi yang dibutuhkan oleh tubuh sudah terpenuhi [20].

Hasil uji tantang dengan virus VNN menunjukkan bahwa ikan kakap putih yang diberi pakan dengan penambahan air seduhan ekstrak jeruk lemon menghasilkan sintasan yang lebih baik (30\%) dibandingkan dengan perlakuan lain maupun kontrol (Gambar 7). Hal ini diduga karena air yang dipanaskan pada suhu tertentu dapat membuat beberapa zat tertentu mati atau menguap, sehingga kandungan zat yang terdapat pada lemon akan hilang atau terinaktivasi.

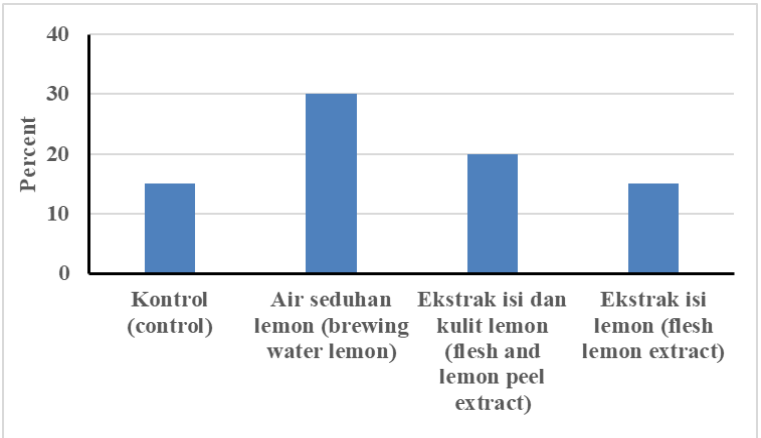

Gambar 7. Sintasan ikan kakap putih setelah dilakukan uji tantang dengan inokulum virus VNN selama 14 hari pemeliharaan

Hal tersebut juga membuktikan bahwa ekstrak jeruk lemon dapat menekan mortalitas ikan kakap putih akibat infeksi virus. Selama ini penggunaan bahan herbal atau tanaman medis lebis banyak digunakan untuk pencegahan maupun pengobatan ikan terhadap infeksi bakteri. Seperti halnya ekstrak kulit jeruk lemon digunakan dalam menghambat pertumbuhan Aeromonas hydrophila, Listonella anguillarum, 
Edwarsiella tarda, Citrobacter freundii [3, 21]. Lebih jauh dilaporkan bahwa adanya kandungan asam sitrat pada ekstrak kulit jeruk lemon dapat menyebabkan protein bakteri mengalami denaturasi yang didahului dengan perubahan struktur molekulnya, dimana akan menyebabkan protein tidak dapat melakukan fungsinya sehingga sel bakteri akan mengalami kematian. Selain itu, senyawa flavonoid dari kulit jeruk lemon dapat menghambat pertumbuhan bakteri dengan merusak dinding sel dan membran sitoplasma bakteri serta mencegah pembelahan bakteri sehingga menyebabkan bakteri tidak dapat berkembang biak [22]. Dari penelitian ini juga terlihat bahwa terdapat peran penting penggunaan kulit jeruk lemon dalam meningkatkan performan darah ikan kakap putih dan menekan mortalitas terhadap infeksi virus dibandingkan dengan penggunaan ekstrak daging jeruk lemon saja.

Hasil pengamatan suhu selama 4 minggu memiliki rentang antara $29-31{ }^{\circ} \mathrm{C}$, sedangkan untuk hasil pengamatan salinitas berkisar antara 30 - 32 ppt. Kisaran suhu standar untuk media hidup ikan kakap putih adalah $28-32{ }^{\circ} \mathrm{C}$ dengan salinitas berkisar antara $28-33$ ppt. Keadaan tersebut sesuai dalam standar SNI (Lates calcarifer, Bloch 1790) [23].

\section{KESIMPULAN}

Dari hasil penelitian ini dapat disimpulkan bahwa pemberian ekstrak daging dan kulit jeruk lemon dapat meningkatkan kadar eritrosit yang berpengaruh nyata terhadap persentase hematokrit dan kadar haemoglobin. Sedangkan air seduhan lemon berperan dalam meningkatkan kadar leukosit, glukosa darah dan lebih mampu menekan mortalitas ikan kakap putih terhadap infeksi virus VNN.

\section{UCAPAN TERIMAKASIH}

Penulis mengucapkan terimakasih kepada teknisi litkayasa Laboratorium Patologi BBRBLPP yang telah membantu dalam penelitian ini.

\section{DAFTAR PUSTAKA}

[1] S.B.M. Sembiring, G.S. Wibawa, K. Mahardika, W. Zeny, \& Haryanti. "Prevalensi infeksi penyakit viral nervous necrosis (VNN) dan iridovirus pada budidaya ikan laut". Media Akuakultur, 13(2), 1-9, 2018.

[2] K. Mahardika, I. Mastuti, D. Roza, D. Syahidah, W.W. Astuti, S. Ismi, \& Zafran. "Pemantauan insidensi penyakit pada ikan kerapu dan kakap di hatchery dan keramba jaring apung di bali utara”. Jurnal Riset Akuakultur, 2019 (inpress).

[3] C. Öntaş, E. Baba, E. Kaplaner, S. Küçükaydin, M. Öztürk, \& M.D. Ercan. "Antibacterial activity of Citrus limon Peel essential oil and Argania spinosa oil against fish pathogenic bacteria". Kafkas Univ. Vet. Fak. Derg., 22 (5), 741-749, 2016

[4] U.M. Nizhar. "Level Optimum Sari Buah Lemon (Citrus limon) sebagai Bahan Penggumpal pada Pembentukan Curd Keju Cottage". Skripsi. Program Studi Teknologi Hasil Ternak. Jurusan Produksi Ternak. Fakultas Peternakan. Universitas Hasanudin. Makasar, pp. 50, 2012.

[5] A.H. Krisnawan, R. Budiono, D.R. Sari, \& W. Salim. "Potensi antioksidan ekstrak kulit dan perasan daging buah lemon (Citrus lemon) lokal dan impor". Prosiding Seminar Nasional, Fakultas Pertanian UMJ "Pertanian dan Tanaman Herbal Berkelanjutan di Indonesia", p. 30-34, 2017.

[6] S.M. Quita. "Evaluation of lemon fruit extract as an antioxidant agent against histopathological changes induced by cyclophosphamide in the testes of albino mice". Electron physician, 8(1), 18241831, 2016.

[7] I.G.A.N. Afsari, H. Fitriani, \& T.A. Suroso. "The effectiveness of lemon juice (Citrus limon) on purkinje cell of white male mice (Mus musculus) cerebellar cortex that exposed by monosodium glutamate (MSG)". Proceedings of International Conference on Applied Science and Health (No. 4, 2019) Science for the mankind: Translating research results into policy and practices, p. 171-176, 2019. 
[8] F. Johnny, Zafran, D. Roza, \& K. Mahardika. "Hematologis beberapa spesies ikan laut budi daya". Jurnal Penelitian Perikanan Indonesia, 9(4), 63-71, 2003.

[9] K. Mahardika, I. Mastuti, \& Zafran. "Pencegahan infeksi Viral Nervous Necrosis (VNN) penyebab black body disease pada kerapu hybrid dengan vaksin sederhana". Prosiding Seminar Nasional Kelautan XII, Fakultas Teknik dan Ilmu Kelautan Universitas Hang Tuah, Surabaya, p. D1-72-79, 2017.

[10] F. Susandi, Mulyana, \& Rosmawati. "Peningkatan Imunitas Benih Ikan Gurame (Osphronemus gouramy Lac.) Terhadap Bakteri Aeromonas hydrophila Menggunakan Rosella (Hibiscus sabdariffa L.)". Jurnal Mina Sains, 3(2), 113, 2017.

[11] R.J. Roberts. "Fish Pathology". Bailliere Tindal, London, 2001.

[12] R.D.D. Nurjannah, S.B. Prayitno, Sarjito, \& A.M. Lusiastuti. "Pengaruh ekstrak daun sirsak (Annona muricata) terhadap profil darah dan kelulushidupan ikan mas (Cyprinus carpio) yang diinfeksi bakteri Aeromonas hydrophila". Journal of Aquaculture Management and Technology, 2(4), 72-83, 2013.

[13] E. Supriyono, Budiyanti, \& T. Budiardi. "Respon fisiologi benih ikan kerapu macan Epinephelus fuscoguttatus terhadap pengunaan minyak sereh dalam transportasi tertutup dengan kepadatan tinggi”. Ilmu Kelautan, 15 (2), 103-112, 2010 .

[14] C.F.C. Paulo, H.S.K. Pedro, A. Elaine, S. Correia, \& B. Bernardo. "Transport of jundiá Rhamdia quelen juveniles at different loading densities: water quality and blood parameters". Journal Neotropical Ichthyology, 7(2), 283-288, 2009.

[15] Bastiawan, D.A. Wahid, M. Alifudin, \& I. Agustiawan. "Gambaran darah lele dumbo (Clarias spp.) yang diinfeksi cendawan Aphanomyces spp. pada $\mathrm{pH}$ yang berbeda".
Jurnal Penelitian Perikanan Indonesia, 7(3), 44-61, 2001.

[16] M.Y. Tsuzuki, K. Ogawa, C.A. Strussmann, M. Maita, \& F. Takashima. "Physiological responses during stress and subsequent recovery at different salinities in adult pejerrey Odontesthes bonariensis". Aquaculture, 200, 349-362, 2001.

[17] Y. Fujaya. "Fisiologi Ikan: Dasar Pengembangan Teknologi Perikanan". Rineka Cipta, Jakarta, pp. 179, 2004.

[18] D. Wahjuningrum, N. Ashry, \& S. Nuryati. "Pemanfaatan ekstrak daun ketapang (Terminalia cattapa) untuk pencegahan dan pengobatan ikan patin (Pangasionodon hypophthalmus) yang terinfeksi Aeromonas hydrophila". Jurnal Akuakultur Indonesia, 7(1), 79-94, 2008.

[19] A.M. Luthfi. "Analisis gula darah ikan nila (Oreochromis niloticus) dari sungai Jagir kota Surabaya Jawa Timur. Sarjana thesis, Fakultas Perikanan dan Ilmu Kelautan, Universitas Brawijaya, 2018.

[20] R. Tifa. "Pengaruh sistem saraf terhadap perilaku ikan". http://www.ktguru.org.

[21] K.N. Tanjung, Sudarno, \& L. Sulmartiwi. "Efektivitas ekstrak kulit jeruk lemon (Citrus limonum) terhadap daya hambat pertumbuhan Aeromonas hydrophila secara in vitro. Berkala Ilmiah Perikanan, 3 (1), 89-93, 2008.

[22] T. Robinson. "Kandungan Organik Tumbuhan Tinggi". Diterjemahkan oleh K. Padmawinata. Penerbit ITB, 1995.

[23] Standar Nasional Indonesia. "Ikan kakap putih (Lates calcarifer Bloch 1790)". SNI 6145.3, Bagian 3: Produksi Induk, 2014. 